History pursuits, and more lately to palæontology, paying especial attention to the fossils of the Skiddaw Slates, which he collected with great diligence and care, accumulating in time a very fine series of these rare Ordovician treasures. Mr. Dover was elected a Fellow of the Geological Society in 1880, and a member of the Geologists' Association in 1881, taking part in the Lake-District long-excursion of the latter body in that year, as one of its directors. In $1890 \mathrm{Mr}$. Dover presented his fine collection of Skiddaw Slate Fossils to the Woodwardian Museum, Cambridge, where it forms a most valuable contribution to our knowledge of the Geology and Fauna of the LakeDistrict rocks.

\title{
SIR ANDREW CROMBIE RAMSAY, KNT., LL.D., F.R.S., F.G.S.
}

Born 1814. Died Deckmber 9Th, 1891.

We regret to record the death of Sir Andrew Ramsay, late Director-General of the Geological Survey, which occurred at his residence, Baumaris, Anglesey, Dec. 9th, 1891, in bis 77th year.

He was educated at Glasgow, and was appointed to the Geological Survey of England and Wales in 1841, and became Local Director in 1845. $\mathrm{He}$ was nominated Professor of Geology at University College in 1848, Lecturer on Geology at the Royal School of Mines in 1851, and was President of the Geological Society in 1862 and 1863. He was elected a F.R.S. in 1849, and Knight of the Order of St. Manrice and St. Lazarus in 1862, and was elected an honorary LL.D. of Edinburgh in 1866. He received the Wollaston Gotd Medal from the Geological Sociey in 1871. On the death of Sir Roderick I. Murchison, Bart., he was made DirectorGeneral of the Geological Survey of the United Kingdom, and of the Museum of Practical Geology in 1872. On his retirement from these offices in 1881, he received the honour of Kinighthood. He presided over the meeting of the British Association at Swansea in August, 1880. He was an Associate of many foreign societies. Sir Andrew Ramsay is author of "The Geology of Arran," "Geology of North Wales," 1858, 2nd edition 1881 ; "Old Glaciers of North Wales and Switzerland," 1860; the "Pbysical Geology of Great Britain," 1878 ; and of very many memoirs, chiefly on theoretical geology.

His life and portrait appeared in the Grologroal Magazini for 1882, Decade II. Vol. IX. pp. 289-293.

Dr. Ferdinand von Rommer, Professor of Geology and Palmontology in the University of Breslau, whose Jubilee as Professor it was intended to celebrate on 10th May, 1892, died at Breslan, on the 14th December, 1891, in his seventy-fourth year. Dr. Roemer was elected a Foreign Member of the Geological Society in 1859, and was awarded the Murchison Medal in 1885 . W, shall gire a notice of this distinguished Geologist in the February Number.Enit. Geor. MAG. 